\title{
SKELETAL CHANGES AND NEPHROCALCINOSIS IN A CASE OF ATHYREOSIS
}

BY

\author{
SEZAI BEDREDDIN TÜMAY, METINE BILGER and NADIR HATEMI \\ From the Paediatric Clinic, University of Istanbut
}

(RECEIVED FOR PUBLICATION MARCH 16, 1962)

One of the well-known characteristic skeletal findings in athyreosis is retardation of bone maturation, the most common manifestations of which are delayed appearance of ossification centres of the carpal bones and the closure of the anterior fontanelle. Other evidences of this retardation of bone maturation have, however, been reported more recently and modern methods of research have shed new light on their pathogenesis. These changes are mostly localized in the vertebrae and the epiphyseal region of the long bones (Andersen, 1955; Debré, Mandé and Abitol, 1948; Evans, 1952; Reilly and Smyth, 1937; Chaptal, Jean, Campo and Carli, 1956). Aside from delayed maturation, hyperostosis and nephrocalcinosis have also been occasionally observed (Naylor, 1955).

The following case is of particular interest because it presented a combination of all the skeletal changes named above.

\section{Case Report}

Fatma, C., a 6-year-old girl, was brought to our clinic because of failure to thrive, inability to walk or talk and difficulty in swallowing because of a large protruding tongue. The patient, the only child of the family, was born after a normal delivery.

Clinical examination on admission showed an unusually short and stunted child (height $71 \mathrm{~cm}$., weight $8 \cdot 3 \mathrm{~kg}$.) with all the classical characteristics of athyreosis (Fig. 1); myxoedematous facies, dryness of the skin and hair, an open anterior fontanelle and an umbilical hernia. In addition to the myxoedema, particularly evident on the eyelids and the back of the hands and feet, an unusual hypertrophy of the shoulder, arm and calf immediately attracted attention, giving the child a pseudo-athletic appearance (Fig. 2).

Biopsy performed on the calf revealed a myxoedematous infiltration, but no signs of true hypertrophy or degeneration of the muscle fibres.

The child had an I.Q. of 6, being classified as an idiot.

The electrocardiogram showed the classical signs of generalized widespread low amplitude waves, but no other abnormality.

Radiological Findings. Only two metacarpal centres; notching of the anterior border of the lumbar and dorsal vertebrae; anterior displacement of the $\mathrm{L}_{2}$ vertebra (Fig. 3); nephrocalcinosis (Fig. 4); hyperostosis of the

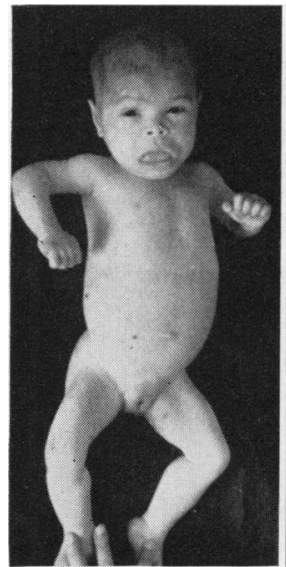

FIG. 1

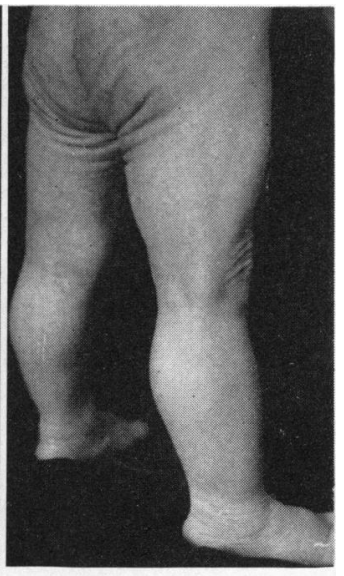

FIG. 2
FIG. 1.-Child showing classical characteristics of athyreosis, myxoedematous facies and dry skin.

Fig. 2.-Myxoedema and hypertrophic musculature.

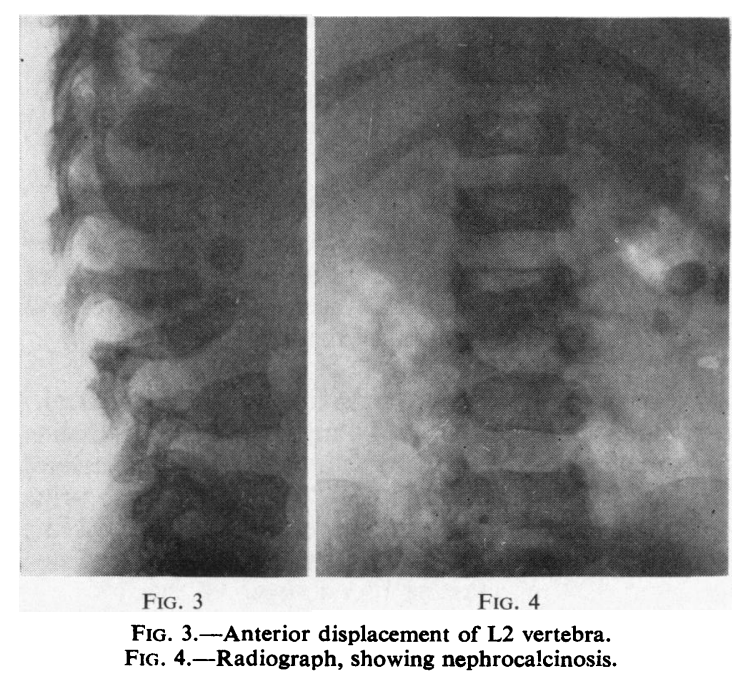




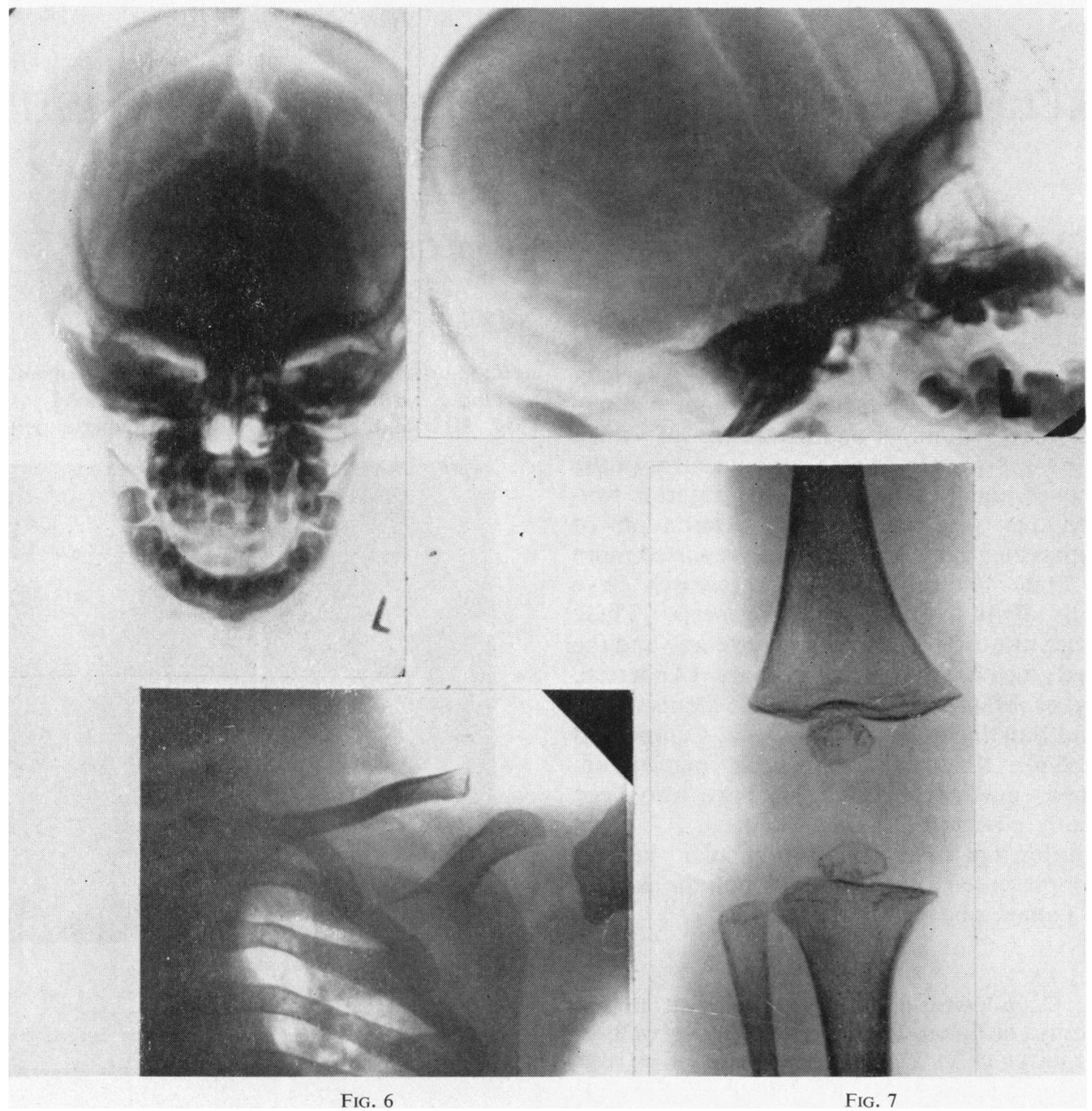

FIG. $5 a$ and b.-Hyperostosis of the base of the skull. FIG. 6.-Underdevelopment of glenoid fossa and scapula.

Fig. 7.-Epiphyseal dysgenesis at lower end of femur and upper end of tibia. base of the skull (Fig. 5a and 5b), and the upper border of the orbits; underdevelopment of the glenoid fossa and scapula (Fig. 6); epiphyseal dysgenesis at the lower end of the femur and upper end of the tibia (Fig. 7).

Biochemical Findings. Serum calcium $9.8 \mathrm{mg} . / 100 \mathrm{ml}$.; inorganic phosphorus $4.4 \mathrm{mg} . / 100 \mathrm{ml}$.; alkaline phosphatase $7 \cdot 5$ Bodansky units; blood cholesterol $208 \mathrm{mg} . / 100 \mathrm{ml}$; total lipids $732 \mathrm{mg} . / 100 \mathrm{ml}$; urine creatine $2.32 \mathrm{mg} . / 24 \mathrm{hr}$.; urine creatinine $150 \mathrm{mg} . / 24 \mathrm{hr}$.; blood creatine $0.34 \mathrm{mg} . / 100 \mathrm{ml}$; blood creatinine $0.50 \mathrm{mg} . / 100 \mathrm{ml}$.; fasting blood sugar $90 \mathrm{mg} . / 100 \mathrm{ml}$.; glucose tolerance test nearly normal. Sulkowitz test, on 24-hour sample of urine, negative.
There was no iodine uptake 24 hours after the ingestion of 10 microcuries of $\mathrm{I}^{\mathbf{1 3 1}}$.

Kidney biopsy, performed on the right healthy kidney, revealed only minor alterations in the tubules consisting of hydropic and granular degeneration.

\section{Discussion}

The vertebral changes observed in our case were first reported by Evans (1952), who pointed out the deformities in the first and second lumbar vertebrae. These deformities, which were more closely studied by Caffey (1956), Thomsen and Vesterdal (1951) and Swoboda and Zimprich (1961), consist 
of a notching located on the anterior border of the second, and more rarely, the first and third lumbar vertebrae. This feature, normal till the end of the first year, persists in cases of athyreosis until much later, our case being 6 years old. Moreover, these vertebrae are extremely underdeveloped and their upper and lower surfaces show a slight convexity.

The fact that the anatomico-pathological study of these vertebrae reveals an underdevelopment of the centre of primary ossification is evidence that this deformity is directly associated with abnormality of maturation. The study of the phases of development of the vertebrae in intrauterine and early postnatal life also supports this point of view. At this stage the radiographs of the bodies of normal vertebrae show obvious notching on the anterior border, which represents the bed of a large vascular sinus, and gradually disappears by the end of the first year. In cases of retardation due to lack of thyroid hormone this appearance is seen up to 5 to 6 years of age.

Another skeletal abnormality due to imperfect development, also present in our case, is in relation to the epiphyseal ends of the long bones. These seem to lose their normal density and present a mottled, spongy or tigroid appearance (Lelong, Joseph, Canlorbe and Scholler, 1955) (Fig. 7). This abnormality, first reported by Langhans in 1897 in two cases of myxoedema, was studied more closely by Looser (1929) who gave a description of its anatomy, and it was later named 'epiphyseal dysgenesis' by Reilly and Smyth (1937).

The ossification of the small bones and epiphyses, which normally starts centrally but follows an eccentric development, consists, in cases of myxoedema, of numerous small centres scattered in the epiphyseal cartilages. These centres, which grow independently from each other, show varying degrees of opacity, and this is responsible for the characteristic picture just described.

The pathogenesis of epiphyseal dysgenesis is not completely clear. Nevertheless, the experiments of Wilkins (1941) performed on thyroidectomized kittens have to some extent helped to explain it. This author has shown that although the rearrangement of cartilage cells before ossification follows a normal course in these animals, this is not immediately followed by normal ossification. This allows abnormal growth of the cartilage cells which soon cover all the epiphyseal zone. As a result the ossification which then takes place is in the form of irregular and scattered independent centres. The fact that this abnormality shows regression during thyroid treatment, indicates that it is related to retarded bony maturation.
Apart from vertebral abnormalities and epiphyseal dysgenesis due to defects of maturation, our case also presents a considerable degree of hyperostosis in some bones. This is particularly evident on the upper border of the orbit and the bones forming the base of the skull (Fig. 5a and 5b). Apart from this, a metopic suture of the frontal bone and the presence of wormian bones are clearly seen on the same radiographs.

Hyperostosis in thyroid insufficiency has been known for a long time. Coryn (1938), in histological sections of these bones, demonstrated that the cortex was abnormally hard and thick. Braid (1951) and Breton, Vandendorf, Dubois and Bubois (1958) reported cases which presented increased density in all the skeletal bones and calcinosis in the soft tissues. Fanconi, Girardet, Schlesinger, Butler and Black (1952) published a case with chronic hypercalcaemia and hyperazotaemia, and Royer and Mégevand (1954) reported a case with craniofacial hyperostosis. The radiological features of these cranial changes have been described in detail by Bellini and Neves (1956). Although these findings can be likened to idiopathic hypercalcaemia, the usual coexistence of wormian bones and metopic sutures, and the lateness in the closure of the anterior fontanelle, are strong points against this diagnosis.

Hyperostosis is sometimes generalized, taking on the character of osteopetrosis. This osteopetrosis, first studied by Jeune and Muller (1959), must be differentiated from Albers-Schönberg disease and idiopathic hypercalcaemia by the presence of other symptoms of hypothyroidism and by the rapid regression that takes place with the administration of thyroid hormone.

Before trying to analyse the pathogenesis of hyperostosis associated with thyroid deficiency, it is helpful to discuss the abnormalities of calcium metabolism and the nephrocalcinosis sometimes observed in these patients. Referring once again to the x-ray pictures of the vertebral column in our patient (Fig. 3), it will be seen that they also reveal a nephrocalcinosis. This condition, which is very rare, was observed by Johnson and White (1952) and Naylor (1955). But it was only in 1958 that Royer, Lestradet and Habib showed a relation between nephrocalcinosis and hypothyroidism. Some of their cases were diagnosed by renal biopsy, some on x-ray and others at autopsy. Histological examinations revealed intracytoplasmic punctuation in the epithelial cells of the distal renal tubules, calcium cylinders and calcinosis of the cortex.

Along with hyperostosis and nephrocalcinosis, disorders in calcium metabolism have also been 
observed in hypothyroidism. Although plasma calcium and phosphate have been found normal and alkaline phosphatase low in most of the cases, hypercalcaemia and hyperphosphataemia have also been reported. Royer and Mégevand (1954), for example, published a case with a blood calcium level of $12.5 \mathrm{mg} . / 100 \mathrm{ml}$., Royer (1959) reported a non-treated case of hypothyroidism aged $7 \frac{1}{2}$ years, with a serum calcium of $13-16 \mathrm{mg} . / 100 \mathrm{ml}$., and Wilkins (1957) reported a case of congenital cretinism with a calcium level of $13.7 \mathrm{mg} . / 100 \mathrm{ml}$.

In patients with hyperostosis, hypercalcaemia has sometimes been observed before thyroid treatment, while in others it has appeared during the administration of hormone. It can therefore be assumed that although it is clearly related to hormonal deficiency in some cases, it can be considered the result of therapy in others.

The bony changes in hypothyroidism discussed above are almost always associated with a positive calcium balance. This is primarily explained by a decrease of faecal calcium output attributable to three different factors. First, as shown by Krane, Brownell, Stanbury and Corrigan (1956) there is a decrease in the faecal excretion of endogenous calcium. Secondly, as shown by Royer (1959), there is a decrease in urinary calcium excretion. Thirdly, it is probable that intestinal absorption of ingested calcium is increased in these cases. Goormaghtigh and Handovsky (1938) have reported that thyroidectomized dogs are hypersensitive to vitamin $\mathrm{D}$, probably due to the slow breakdown of sterols associated with the hypothyroid state. It is therefore probable that hypercholesterolaemia and hypersensitivity to vitamin D result from the same origin, i.e. disorder in the breakdown of sterols.

It has been shown that in hyperparathyroidism, there is an increased mobilization of calcium from the bone, resulting in hypercalcaemia and nephrocalcinosis (Wilkins, 1957). These findings suggest that the hyperostosis observed in hypothyroidism may be due to a decrease in calcium turnover in the bones, which has in fact been shown to exist, by Krane et al. (1956), and to be due to insufficiency in osteoclastic activity. They demonstrated a slower rate of osteolysis than of osteogenesis in these patients, resulting in an accumulation of calcium in the bone.

If a correlation is attempted among these various disturbances in calcium metabolism, it is seen that there is on the one hand an accumulation of calcium in the bones and on the other an overabsorption of calcium from the intestines. These two abnormalities are in equilibrium most of the time, and calcium in the bones accumulates normally.

In some instances, however, the absorption of calcium gains predominance and hypercalcaemia occurs, which may be followed by calciuria and eventually nephrocalcinosis. That nephrocalcinosis is not always seen simultaneously with hypercalcaemia, as was the case in our patient, may be explained by the fact that hypercalcaemia is not continuous but occurs at intervals. Nevertheless, we would like to stress the point that undue administration of vitamin $D$ to these children may be extremely harmful before, as well as during, treatment with thyroid.

The factors which upset the equilibrium between calcium absorption and its deposition in the bones, cannot always be demonstrated, but are perhaps related to such factors as excessive administration of vitamin $D$ and the occurrence of calcium saturation in a patient with hypothyroidism whose skeletal growth is very slow. Moreover, it is also possible that factors influencing local calcium metabolism in the kidneys play a part in the precipitation of calcium salts. These explanations are theoretical. Nevertheless, the animal experiments performed by Royer et al. (1958) seem to favour them. These authors observed hypercalciuria in 20 mice 13 to 19 weeks after thyroidectomy. In 15 there was also nephrocalcinosis, but hypercalcaemia could be detected only in three. The results of these experiments, which can be compared to the findings in children, suggest that nephrocalcinosis is especially related to hypercalciuria.

\section{Summary}

The authors present a case of athyreosis with skeletal changes and nephrocalcinosis and discuss the various factors that may play a part in the pathogenesis of this disorder.

\section{REFERENCES}

Andersen, H. (1955). Changes of the spine in children with myxoedema. Acta paediat. (Uppsala), 44, Suppl. 103, p. 102 .
my myxoedema. Acta paediat. (Uppsala), 44, Suppl. 103, p. 102 .
Bellini, M. A. and Neves, I. (1956). The skull in childhood myxedema : its roentgen appearance. Amer. J. Roentgenol., 76, 495.

Braid, F. (1951). Hypothyroidism in childhood. Brit. med. J., 1, 1169.

Breton, A., Vandendorf, F., Dubois, R. and Bubois, O. (1958). A propos d'un cas de myxoedème avec condensation osseuse. Pédiatrie, 13, 100.

Caffey, J. (1956). Pediatric X-ray Diagnosis, 3rd ed. Year Book Publishers, Chicago.

Chaptal, J., Jean, R., Campo, C. and Carli, N. (1956). Etude sur le myxoedème de l'enfant. Arch. franc. Pédiat., 13, 509.

Coryn, G. (1938). Les affections endocriniennes du squelette. Presse méd., 46, 228.

Debré, R., Mandé, R. and Abitol, S. (1948). La dysgenesie epuphysaire du xymoedeme. Arch. frans. Pédiat., 5, 75.

Evans, P. R. (1952). Deformity of vertebral bodies in cretinism. J. Pediat., 41, 706.

Fanconi, G., Girardet, P., Schlesinger, B., Butler, N. and Black, J. (1952). Chronische Hypercalcämia kombiniert mit Osteosklerose, Hyperazotämie, Minderwuchs und kongenitalen Missbildungen. Helv. paediat. Acta, 7, 314. 
Goormaghtigh, N. and Handovsky, H. (1938). Vitamin D, thyroide et pathologie vasculaire. Bull. Acad. roy. Med. Belg., 6 ser., 3,132 .

Jeune, M. and Muller, J. M. (1959). L'ostéopétrose myxoedémateuse. Pédiatrie, 1443.

Johnson, F. and White, H. (1952). Cited by Mégevand, A., Mathieu, H. and Royer, P. (1961). Anomalies squelettiques et troubles du métabolisme du calcium dans les insuffisances thyroidiennes de l'enfant. XVIII Congrès de l'Ass. des Pédiatres de langue française, Genève, 1961. Rapports I, p. 205.

Krane, S. M., Brownell, G. L., Stanbury, J. B. and Corrigan, H. (1956). The effects of thyroid disease on calcium metabolism in man. J. clin. Invest., 35, 874.

Langhans, T. (1897). Anatomische Beiträge zur Kentniss der Cretinen. Virchows Arch. path. Anat., 149, 155.

Lelong, M., Joseph, R., Canlorbe, P. and Scholler, R. (1955). L'aspect cercle des noyaux d'ossification chez l'enfant myxoedémateux. Ann. Pédiat., 31, 1077.

Looser, E. (1929). Die Kretinenhüfte. Schweiz. med. Wschr., 10, 1258.

Naylor, J. M. (1955). A case of hypothyroidism with nephrocalcinosis. Arch. Dis. Childh., 30, 165.
Reilly, W. A. and Smyth, F. S. (1937). Cretinoid epiphyseal dysgenesis. J. Pediat., 11, 786.

Royer, P. (1959). L'hyperparathyroidisme et le problème des hypercalcémies chez l'enfant. (Cours d'endocrinolie infantile. Centre International de L'Enfance, Paris.)

- Lestradet, H., and Habib, R. (1958). Les hypercalcémies et les néphrocalcinoses au cours du myxoedème congénital. Arch franc. Pédiat., 15, 896.

franç. Pediat., 15, 896. (1954). Les anomalies squelettiques du myxoedème congénital et leur valeur diagnostique. ibid., 11,125

Swoboda, W. and Zimprich, H. (1961). A propos du diagnostic du nyxoedème congénital. XVIII Congrès de l'Association des Pédiatres de Langue française, Genève, 1961. Communications, p. 34 .

Thomsen, G. and Vesterdal, J. (1951). Atypical Hurler's syndrome. Acta radiol. (Stockh.), 35, 331.

Wilkins, L. (1941). Epiphysial dysgenesis associated with hypothyroidism. Amer. J. Dis. Child., 61, 13.

- (1957). The Diagnosis and Treatment of Endocrine Disorders in Childhood and Adolescence, 2nd ed. Thomas, Springfield, Illinois. 